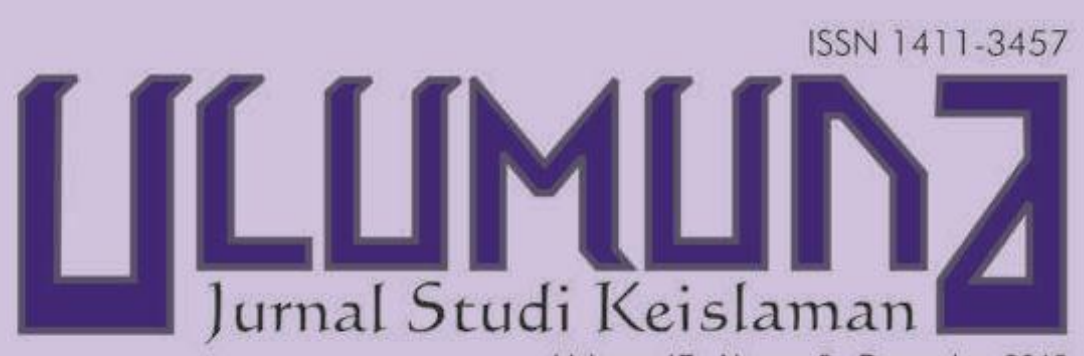

Volume 17· Nomor 2 - Desember 2013

TERAKREDITASI [3, SK Dirjen Dik: Kenmikind Nomor: 56 DIKTIKep 2012. Targgal 24 junt 2012

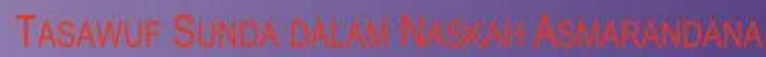
$767(6)$

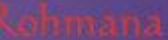

(s):

DALAM TRADISI KEAGM

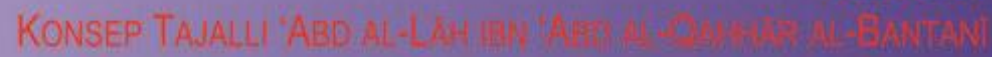

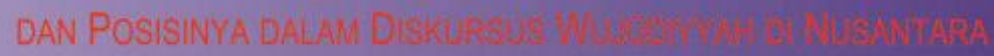

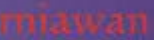

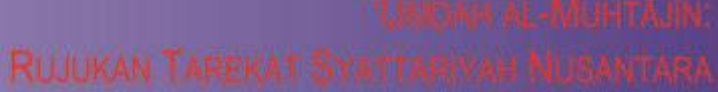

manherit

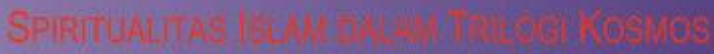

1) thits

YOWMAN:

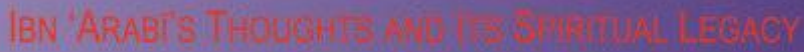

3ेputra

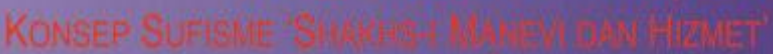

GUIEN

(umayi

Acoxuma

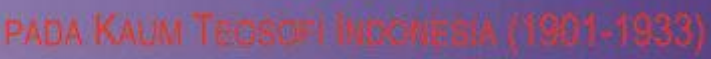

Babei

BASAWUF

Tanany

upinkat 


\section{DAFTAR ISI}

\section{Pedoman Transliterasi}

\section{1-258 • Jajang A Rohmana}

"Tasawuf Sunda dalam Naskah Asmarandana

Ngagurit Kaburu Burit (OR. 7876)”

259-274 • Mashadi

"Konteks dan Corak Mistisisme Islam

dalam Tradisi Keagamaan Masyarakat Gorontalo"

275-302 • Ade Fakih Kurniawan

"Konsep Tajalli 'Abd al-Lāh ibn 'Abd al-Qahhār

al-Bantanī dan Posisinya dalam Diskursus

Wujūdiyyah di Nusantara"

303-322 • Damanhuri

“Umdah al-Muhtàjīin:

Rujukan Tarekat Syattariyah Nusantara"

\section{3-346 • Munawir Haris}

"Spiritualitas Islam dalam Trilogi Kosmos"

347-358 - Hans Abdiel Harmakaputra

"Becoming a Perfect Human:

Ibn 'Arabî's Thoughts and Its Spiritual Legacy"

359-386 • Sulaiman Al-Kumayi

"Konsep Sufisme 'Shakhs-i Manevi dan Hizmet'

Muhammad Fethullah Gülen"

387-420 • Media Zainul Bahri

"Gagasan Pluralisme Agama

pada Kaum Teosofi Indonesia (1901-1933)"

421-440 • Lalu Supriadi

"Studi Komparatif Pemikiran Tasawuf

al-Ghazali dan Ibn Taimiyah"

\section{LAMPIRAN-LAMPIRAN}




\section{PEDOMAN TRANSLITERASI}

\begin{tabular}{|c|c|c|c|c|c|c|}
\hline 1 & $=$ & $\mathbf{a}$ & & $\dot{\varepsilon}$ & $=$ & $\mathrm{g}$ \\
\hline ب & $=$ & $\mathbf{b}$ & & ف & $=$ & f \\
\hline$ت$ & $=$ & $\mathbf{t}$ & & ق & $=$ & $q$ \\
\hline$\dot{H}$ & $=$ & th & & ك & $=$ & $\mathbf{k}$ \\
\hline ج & $=$ & $\mathfrak{j}$ & & J & $=$ & 1 \\
\hline$\tau$ & $=$ & ha & & s & $=$ & $\mathrm{m}$ \\
\hline$\dot{\tau}$ & $=$ & $\mathbf{k h}$ & & ن & $=$ & $\mathbf{n}$ \\
\hline د & $=$ & d & & و & $=$ & $\mathbf{w}$ \\
\hline ذ & $=$ & dh & & ○ & $=$ & $\mathbf{h}$ \\
\hline Ј & $=$ & $\mathbf{r}$ & & $\varepsilon$ & $=$ & , \\
\hline j & $=$ & $\mathbf{z}$ & & ي & $=$ & $\mathrm{y}$ \\
\hline س س س & $=$ & $\mathbf{s}$ & & & & \\
\hline 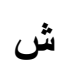 & $=$ & sh & \multicolumn{4}{|c|}{ Untuk Madd dan Diftong } \\
\hline ص & $=$ & ș & i & $=$ & \multicolumn{2}{|c|}{$\bar{a}$ (a panjang) } \\
\hline ض & $=$ & d & إي & $=$ & \multicolumn{2}{|c|}{$\overline{1}$ (i panjang) } \\
\hline b & $=$ & $t$ & 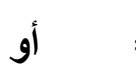 & $=$ & \multicolumn{2}{|c|}{$\bar{u}$ (u panjang) } \\
\hline ظ & $=$ & $\mathrm{z}$ & 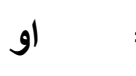 & $=$ & \multicolumn{2}{|c|}{ aw } \\
\hline$\varepsilon$ & $=$ & ‘ & 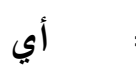 & $=$ & \multicolumn{2}{|l|}{ ay } \\
\hline
\end{tabular}

Contoh penulisan dengan transliterasi:

(a'üdhu bi al-Lāh min al-shaytān al-rajim); اعوذ بالله من الشيطان الرجيم

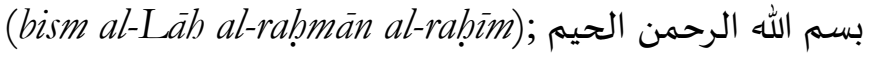

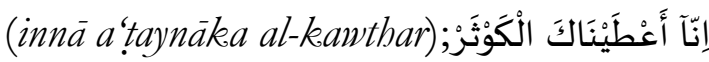

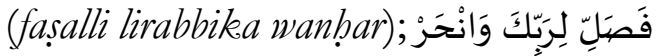

(șabāḥ al-khayr). صبباح الخير 


\title{
KONTEKS DAN CORAK MISTISISME ISLAM DALAM TRADISI KEAGAMAAN MASYARAKAT GORONTALO
}

\author{
Mashadi \\ (Fakultas Ushuluddin dan Dakwah IAIN Sultan Amai Gorontalo \\ Email: mashadimaili@yahoo.co.id)
}

Abstract: Many studies on religion generally focus on two important points. The first is the discussion about God and His Attributes, such as invisible, sacred and absolute. The second point relates to social dimensions of religion which are profane, empirical and relative. These are two points that this paper attempts to reveal when elucidating mysticism in the context of Muslim local tradition in Gorontalo. This study shows that Muslim ritual traditions of Gorontalo are deeply influenced by Sufi order's mysticisms and practices. These traditions are expressed in various local rituals and cultures. This integration of religion and culture affirms the pattern of religious expression which is unique and localized. The appreciation of the existence of God in this locale is realized through the chanting and supplication to the souls of forebears and through the event of public gratitude when the people are blessed with abundant bounties.

Abstrak: Kajian mengenai isu keagamaan dengan beragam definisinya, akan berujung pada sebuah pemahaman bahwa refleksi terhadap agama, pada akbirnya, akan berkaitan dengan gambaran ketubanan yang bersifat gaib, sakral, dan absolut (mutlak) di satu sisi, dan di sisi lain wilayah keagamaan yang berkaitan dengan refleksi agama oleh manusia dengan kebudayaannya, yang bersifat nyata, profan, dan relatif (nisbi). Dalam dua wilayah pemahaman keagamaan tersebut, kajian mengenai mistisisme dalam konteks tradisi Islam lokal Gorontalo akan difokuskan. Jika kita menelisik lebih dalam pada realitas kehidupan religius masyarakat Gorontalo, sudut pandang antropologis, akan ditemukan suatu fakta bahwa praktek keberagamaan mereka adalah praktek keagamaan yang banyak diwarnai oleh praktek tarekat dalam bentuk ritual peribadatan yang bercorak mistis. Ritual-ritual tersebut wujud dan termanifestasi dalam berbagai tradisi upacara keagamaan yang dilatari oleh budaya agama dan budaya sosial.

Keywords: mistisisme, tradisi keagamaan, masyarakat Gorontalo, tarekat, adat, syara'. 
FENOMENA keagamaan dalam masyarakat adalah fenomena yang hampir sama dengan usia manusia itu sendiri, baik agama yang dipahami dalam konteks primitif, maupun agama yang dipahami dalam konteks modern. Hal demikian kemudian memungkinkan agama itu menjadi sangat "memanusia" (bumanisible), yakni bahwa dengan hadirnya kehidupan manusia di dunia ini, memungkinkan agama itu ada dan hadir di dunia. Bahkan istilah inipun kemudian memungkinkan manusia dikategorikan sebagai makhluk yang beragama (religious buman). Konteks demikian memberikan pemahaman bahwa agama sebagai hal yang fitrah (natural) pada diri manusia selalu berkaitan dengan perkembangan kebudayaan manusia itu sendiri. Dengan demikian antara agama dan budaya suatu masyarakat selalu terdapat kaitan yang signifikan. Dalam konteks tersebut, agama dalam terma universalnya dapat dipahami sebagai seperangkat aturan dan peraturan yang mengatur hubungan manusia dengan dunia gaib, khususnya dengan Tuhannya, mengatur hubungan manusia dengan manusia lainnya, dan hubungan manusia dengan lingkungannya. ${ }^{1}$

Berdasarkan hal demikian, maka ada dua kategori refleksi keagamaan bagi manusia. Pertama, agama yang bersumber dan direfleksikan berdasarkan tatanan wahyu yang diturunkan dari Tuhan, dalam konteks ini agama menjadi fenomena normatifdogmatis. Kedua, agama yang direfleksikan berdasarkan tatanan kemanusiaan dan kebudayaannya, dimana agama menjadi fenomena yang historis. Dari dua corak refleksi keagamaan di atas, maka antara refleksi satu dengan yang lainnya memiliki kaitan dan pengaruh yang sangat kuat bahkan saling memberi warna dan perspektif.

Mendiskusikan tradisi Islam dalam kajian antropologi akan selalu dilihat dalam dua konteks, yakni tradisi religiusitas yang berkaitan dengan cita-cita keagamaan dan tradisi budaya lokal. Perjumpaan kreatif antara nilai universal dari agama dengan budaya lokal telah menghadirkan corak ajaran Islam dalam kesatuan spiritual dengan corak budaya yang plural. Di Indonesia, dengan sebuah studi terhadap Islam dengan konsep seperti ini, tidak saja akan menemukan keterkaitan historis

1Parsudi Suparlan, Ilmu Antropologi (Jakarta: Bhratara, 1988), v. 
dengan realitas kesejarahan Islam, tetapi juga akan menemukan satu sisi penting dari awal proses transformasi intelektual Islam yang bertolak dari nilai-nilai universalisme Islam yang dikategorikan sebagai tradisi besar dengan tata nilai dalam seting kultural dan struktural tertentu yang sudah terpola sebelumnya. ${ }^{2}$

Berkaitan dengan hal tersebut, ada beragam cara seorang Muslim dalam mengapresiasi dan mengaktualkan nilai-nilai keislaman yang diyakininya. Demikian halnya beragam cara seorang Muslim mendekati, dalam konteks melakukan proses penyembahan terhadap Tuhannya. Konteks tersebut menjadi niscaya mengingat Islam sebagai sebuah sistem keyakinan pun diimani secara beragam oleh umatnya, bahkan sejak awal kehadiran Islam di dunia ini. Hal tersebut dapat dipahami bahwa dalam Islam terdapat beberapa jalan menuju/mendekati Tuhan, yakni dengan syariat, tarekat, dan makrifat.

Di Gorontalo, Islam diapresiasi oleh masyarakatnya dalam konteks dan paradigma yang menjunjung tinggi nilai-nilai budaya lokal, yang mana konteks keberagamaan tersebut berada nilai yang telah terwarisi sejak Gorontalo masih merupakan wilayah kerajaan di masa lampau. Islam Gorontalo merupakan agama yang menyebar dari tanah Ternate, yang secara historis memiliki benang merah dalam tata upacara dan ritual keagamaan, termasuk yang berkaitan dengan unsur-unsur mistik yang hadir pada setiap tata upacara dan tata ritual keislaman.

\section{Sekilas Tentang Islamisasi Kebudayaan Gorontalo}

Berdasarkan peta penyebaran agama Islam di Nusantara oleh Tugiyono, pusat dan sumber penyebarannya adalah kerajaan Ternate, sebagai kerajaan Islam yang timbul di bagian timur Indonesia sejak tahun $1430 \mathrm{M}$. Perlu dicatat bahwa Islam dari Ternate menuju pantai Timur Sulawesi pada awalnya memasuki kawasan Tomini ke daerah Palasa yang sudah dikenal sejak abad XV pada saat itu sebelum bernama Tinombo. ${ }^{3}$ Menurut A. Mopangga Islam dimasukkan dan disebarkan oleh muballigh

2Syamsul Arifin dkk., Spiritualisasi Islam dan Peradaban Masa Depan (Yogyakarta: SIPRESS, 1996), 50-1.

3Tugiyono, Atlas dan Lukisan Sejarah Nasional Indonesia (Jakarta: Baru, 1982), 72 . 
Ternate pada abad ke XIV. Muballigh tersebut sewaktu kembali dari Aceh mempelajari aqidah Islam, tersesat dalam perjalanan pulang ke Ternate terbawa arus ombak laut ke teluk Tomini, Palasa bukan ke Gorontalo. ${ }^{4}$

Dengan demikian masuknya Islam ke Gorontalo punya kaitan erat dengan keberadaan teluk Tomini Barat, yakni daerah Palasa yang sudah terkenal pada saat itu, terutama masa abad ke XV dan XVI. Kuno Kaluku ${ }^{5}$ juga berpandangan bahwa pada tahun 1430, raja Gorontalo yang bernama Walango berangkat ke teluk Tomini Barat, daerah Palasa untuk membuka tanah-tanah perkebunan. Sementara Raja pengganti Walango, yaitu Polamolo, melakukan pula perjalanan ke daerah itu dengan maksud yang sama, dan dia sempat kawin di Palasa. Dalam kaitan tersebut S.R. Nur ${ }^{6}$ mengungkapkan bahwa Raja Amai, raja Utara yang kedua Kerajaan Gorontalo pada tahun 1525, melakukan perjalanan dinasnya ke daerah-daerah jajahan Gorontalo di teluk Tomini Barat dan kawin di sana, daerah Palasa. Dalam perjalanan dinasnya di Palasa, Amai bertemu dengan puteri Raja Palasa (bergelar Ogomonjolo; yang punya sifat air dingin) yang bernama Owutango, yang sudah menerima Islam dari Kesultanan Ternate.

Ketika hendak mempersunting Putri Owutango, Raja Amai disyaratkan untuk: (1) Raja dan rakyatnya harus diislamkan, (2) adat istiadat yang berlaku dikalangan rakyat Gorontalo harus bersumber pada Kitab Suci al-Qur'an. Dengan diterimanya persyaratan tersebut, berlangsunglah pesta perkawinan antara Raja Amai dan Putri Owutango, putri raja Ogomonjolo, penguasa Palasa, pada tahun 1525. Selang beberapa hari setelah pernikahan dilangsungkan, suami istri ini dilepas oleh orang tua mantu Raja Palasa untuk berangkat menuju Gorontalo. ${ }^{7}$

${ }^{4}$ A. Mopangga, Sejarah Kampung Empat; Siduan, Sipayo, Soginti, Bunuyo (Makalah, 1997), 1.

${ }^{5}$ Kuno Kaluku, Adat dan Agama Islam (T.T. T.P.Gorontalo), 34.

'S.R. Nur, Islam dan Etos Kerja Masyarakat Gorontalo (Jakarta: Yayasan Festival Istiqlal, 1996), 131.

${ }^{7}$ Baca selengkapnya dalam Ibrahim Polontalo, Masuk dan Berkembangnya Islam di Gorontalo Sejak. Awal Abad Ke XVI Sampai Abad Ke XIX (Makalah; IKIP Negeri Gorontalo, 2003), 2. 
Dari fakta sejarah tentang awal masuknya Islam di Gorontalo di atas, tampak bahwa warna Islam tersebut dipengaruhi oleh persyaratan yang dikemukakan oleh putri Owutango ketika Raja Amai mempersuntingnya, yakni bahwa adat kebiasaan masyarakat harus bersumber pada Kitab Suci alQur'an. Konteks relasi masuknya Islam dari peristiwa pernikahan Raja Amai yang mempersunting Putri Owutango tersebut juga dapat dipahami sebagi proses pewarisan Islam melalui perkawinan, yang mana corak keislaman yang diamalkan oleh orang Palasa dan kawasan Tomini umumnya, adalah Islam yang disebarkan oleh guru-guru agama dari Kesultanan Ternate. Dengan demikian corak keislaman yang diwarisi oleh raja Amai beserta rakyatnya pun secara tidak langsung diwarnai oleh corak Islam Ternate.

Dalam implementasinya, kehidupan keagamaan di bawah naungan din al-Islàm sejak zaman Raja Eyato sebagai peletak dasar keberislaman di Gorontalo, hingga saat ini masih tetap dipertahankan oleh warga dan umat Islam Gorontalo, seperti cirinya dari awal, yakni corak keberislaman yang selalu dapat dijadikan sandaran oleh adat kebiasaan dan kebudayaan rakyat Gorontalo, seperti yang diinginkan oleh Putri Owutango ketika pertamakali menerima pinangan Raja Amai. Berkaitan hal tersebut, dalam perkembangannya kemudian dikenal falsafah lokal orang Gorontalo, yakni "Adati bula-bulaa to saraa, saraa bulabulaa to Kur'ani" yang diartikan sebagai "Adat bersendi Syara', Syara' bersendi Kitabullah”. Dalam prakteknya hampir seluruh peristiwa upacara adat akan selalu disandarkan pada nilai dan ritual Islam. Konteks tersebut dapat kita lihat utamanya dalam upacara pernikahan, pengurusan jenazah/kematian, ulang tahun, naik rumah baru, menyambut tamu, pemberian gelar dan kehormatan, maulid Nabi, dan lain-lain. Demikian halnya sebaliknya, banyak pula ritual agama (yang ada dalam syariat) yang dalam pelaksanaannya, dibarengi dengan ritual adat, seperti shalat Jum'at, dua shalat hari raya (Idul Fitri dan Idul Adha), Isra' Mi'raj, dan Malam Tumbiletohe (malam pasang lampu pada tiga hari terakhir Ramadhan). ${ }^{8}$

${ }^{8}$ Berdasarkan klasifikasi yang dilakukan oleh Ibrahim Polontalo, adat Gorontalo yang disandarkan pada syariat, yang dianggap islami, antara lain: 
Dalam konteks penyebaran Islam, menyangkut asal-usul Islam yang ada di bumi Gorontalo, seperti yang dikemukakan di atas, nampak bahwa terdapat benang merah atau paling tidak pengaruh Islam Ternate yang dapat kita saksikan dalam beberapa ritual Islam. Salah satu ritual yang masih kuat dan diduga merupakan warisan budaya Islam Ternate, adalah pelaksanaan ritual shalat Jumat, yang mana baik dari segi prosesi, simbol busana, dan istilah-istilah yang digunakan masih sangat mirip, ${ }^{9} \mathrm{di}$ samping ritual-ritual lainnya.

\section{Paradigma Tradisi Keberislaman Masyarakat Kota Gorontalo}

Berdasarkan data demografi yang ada, kota Gorontalo merupakan suatu kawasan di Provinsi Gorontalo yang dihuni oleh penduduk yang mayoritas beragama Islam. Sejak awal keberadaan Islam sebagai agama dan keyakinan resmi dikalangan masyarakat Gorontalo, sejak itu pulalah Islam menjadi sandaran dan rujukan bagi keseluruhan aktivitas hidup masyarakat gorontalo, baik itu yang berkaitan dengan ritual atau syariat, maupun aktivitas tersebut yang berkaitan dengan adat dan

adat perkawinan, pelaksanaan kematian, pelaksanaan ibadah mahdah, mengatur hubungan sesama manusia, pembinaan remaja, pembinaan kesenian, pembinaan rakyat dan pemerintah, pembinaan kehidupan yang aman dan damai dimasyarakat, menghormati tamu, membina kehidupan sosial keagamaan, dan pembinaan rumah tangga. Lihat selengkapnya dalam Ibrahim Polontalo, Sultan Amai Pencetus Sejarah Islam di Gorontalo (Makalah Seminar, 1999), 8-10.

${ }^{9}$ Pelaksanaan jumatan atau ritual jumat diawali dengan penyampaian ritual oleh qhadi atau yang dipercayakan kepada khalifah di rumah khalifah (rumah dinas) 2 (dua) jam sebelum pelaksanaan ritual dimulai (di Ternate penyampaian Jum'atan dilaksanakan oleh Jo Khalem atau Qhadi terhadap Sultan di istana sultan Ternate). Selanjutnya pelaksanaan ritual Jumat dilaksanakan di masjid besar (masjid agung), atau masjid sultan (Ternate). Diawali dengan kehadiran para jama'ah, termasuk para Qadhi, Imam, Khatib, Syaradaa, Mufti, Bilal, dan Kasisi (tergabung dalam Bowatulo Syara; Gorontalo, Bobato Akbirat; Ternate) yang mengambil sisi kiri mimbar shaf bagian depan. Adapun Baate, Kimalaha, Olowala lo Pulanga, Olowibi lo Pulanga (tergabung dalam Buwatulo Aadati; Gorontalo, Bobato Dunia; Ternate) mengambil sisi kanan mimbar pada shaf bagian depan. Baik Buwatulo Syara dan Buwatulo Aadati, masing-masing menggunakan busana dengan ciri khas, yang antara Gorontalo dan Ternate terdapat persamaan-persamaan yang signifikan. 
kebiasaan sehari-hari. Hal demikian dapat dipahami, bahwa Gorontalo dikenal dengan falsafahnya, yakni: "Adati bula-bulaa to saraa, saraa bula-bulaa to Kur'ani" yang diartikan sebagai "Adat bersendi Syara', Syara' bersendi Kitabullab". ${ }^{10}$ Konteks tersebut yang selanjutnya menjadi bingkai dari penciri tradisi Islam Gorontalo.

Nilai kearifan tersebut merupakan falsafah hidup masyarakat Gorontalo yang telah dirumuskan sejak Raja Amai yang konsepnya mengalami penyempurnaan sebanyak tiga kali hingga Raja Eyato dengan konsep seperti yang kita kenal sekarang. Kearifan lokal Gorontalo seperti yang tersimpulkan dalam falsafah "Adat bersendi Syara', Syara' bersendi Kitabullah" menjadi warna dan corak tersendiri bagi pelaksanaan dan pengimplementasian nilai-nilai agama di bumi Gorontalo. Nilainilai kearifan tersebut telah menjadi pemberi spirit bagi keseluruhan aktivitas hidup masyarakat Gorontalo.

Dalam berbagai perspektif kearifan lokal Adati bula-bulaa to saraa, saraa bula-bulaa to qur'ani, ditanggapi dan dipersepsikan oleh berbagai kalangan sebagai penentu bagi perjalanan dan konstruksi budaya masyarakat Gorontalo pada masa lalu menuju masa depannya yang civilized (berperadaban). Konteks tersebut dapat kita baca dalam berbagai karya literatur intelektual dan pakar budaya Gorontalo, baik yang telah berusia sepuh, bahkan di antara mereka ada yang telah almarhum, maupun cendekiawan muda yang semakin banyak bermunculan. Beberapa di antaranya misalnya Elnino ${ }^{11}$ yang berhasil memberikan pemetaan predikat kehormatan (ilomata) terhadap ketiga tokoh yang berperan dalam memikirkan rumusan konsep kearifan lokal masyarakat Gorontalo semenjak rumusan awal

${ }^{10}$ Kearifan tersebut dapat dipahami bahwa segala sesuatu harus berdasarkan syara' yang bersumber dari al-Quran, sehingga adat yang bertentangan dengan itu dinyatakan tidak berlaku. Sehubungan dengan hal itu, adati lou ngalaqa/ motolongalaqa pun disesuaikan dengan syariat Islam. Lihat Alim S. Niode. Gorontalo: Perubahan Nilai-nilai Budaya dan Pranata Sosial (Jakarta: Pustaka Indonesia Press, 2007), 69; Ibrahim Polontalo, Adat Bersendikan Syara, Syara Bersendikan Kitabulah sebagai Dasar Pengembangan Budaya dan Pelaksanaan Islam di Gorontalo (Makalah pada Seminar Nasional BPKI-KTI di Gorontalo, 2003), 6-12.

${ }^{11}$ Lihat, Elnino, Islam dan Perdaaban Gorontalo dalam Menggagas Masa Depan Gorontalo (Gorontalo: 2006), 410-1. 
dari Olongia (raja) Amai hingga konsep paripurna Olongia Eyato yang hingga kini masih dijunjung tinggi sebagai kearifan lokal masyarakat Gorontalo. Menurutnya, selain Raja Amai yakni Raja Matolodulakiki (putra Raja Amai) dan Raja Eyato berhasil memperoleh predikat ilomata melalui pengakuan seluruh rakyat, oleh karena jasanya dalam menyebarluaskan ajaran Islam diseantero negeri Gorontalo pada masanya. Di samping itu kedudukan hukum Islam berhasil disetarakan dengan hukum adat yang berlaku ketika itu, dengan prinsip "Adati bulo-buloa to Syara'a, Syara'a bulo-bulo'a to Adati". Di era kekuasaan Raja Matolodulakiki inilah Islam resmi menjadi agama kerajaan, di samping Raja Matolodulakiki juga berhasil mengkampanyekan kesetaraan hak dan kewajiban setiap manusia. Bagi beliau perbedaan status seseorang terutama diukur dari kedalaman ilmu dan ketinggian akhlakul karimah. Keturunan dan jumlah harta yang dimiliki menjadi pertimbangan terakhir dalam menentukan status sosialnya. Predikat ilomata yang diraih Raja Matolodulakiki merupakan ilomata kedua setelah yang pertama diraih oleh Raja Matolodulaa, raja pendahulu Raja Amai yang diklaim sebagai pemimpin pra Islam Gorontalo yang banyak menciptakan karyakarya agung.

Pasca era Raja Matolodulakiki, perubahan progresif dan perolehan predikat ilomata selanjutnya adalah yang didapatkan oleh Raja Eyato (pelanjut Raja Matolodulakiki), yang berhasil memprakarsai sumpah "Uduluwo Lo Ulimo Lo Pohalaa", sumpah yang berhasil mempersatukan Gorontalo dan Limboto setelah bertikai selama lebih dari 200 tahun. Dalam pandangan lain Alim S. Niode mengemukakan bahwa prinsip "Adati hula-bulaa to saraa, saraa bula-bulaa to kuru'ani" (di Minang "Adat bersendi Syara', Syara' bersendi Kitabullah"), merupakan formulasi nilainilai lokal Gorontalo, yang oleh faktor eksternal dan internal mempengaruhi perubahan sosial, menjadikan prinsip tersebut menjadi mozaik culture, sehingga diperlukan langkah strategis dalam menemukan dan mengenali keselarasan adat dan agama, yakni dengan melakukan rekonstruksi budaya. ${ }^{12}$

${ }^{12}$ Alim S. Niode. ASQ (Aadati bula-bulaa to sara, saraa bula-bulaa to kuruani) Sebagai Ideologi Lokal (Upaya Menemu Kenali Keselarasan Adat dan 
Sejak rumusan pertama oleh Sultan Amai (1532-1550), telah terbentuk paradigma keberagamaan yang bercorak adat, yang mana paradigma tersebut berhasil membentuk watak kebudayaan Islam yang bersumber dari teori centrifugal, yang melahirkan versi Islam yang diadatkan. Versi tersebut telah melahirkan dua kearifan sebagai parameter dalam pengembangan kebudayaan Islam di kerajaan Gorontalo. Kearifan tersebut meliputi:

1. Kearifan Nilai. Segera setelah Raja Amai tiba dari Palasa bersama rombongan adalah melaksanakan Shalat Dhuhur secara berjamaah di lapangan terbuka di Hunto Kelurahan Biawu, setelah itu mereka merencanakan dan bersegera membangun mesjid, dan mempercepat terwujudnya pembangunan mesjid, karena tiga hari berikutnya telah tiba hari Jumat.

2. Kearifan Pola Syariat. Dalam rangka mengembangkan tiga macam nilai Islam di atas, sebagai sumber budaya dalam peradaban Islam di Kerajaan Gorontalo, disusunlah 185 macam pola syariat yang didasarkan pada prinsip versi Islam yang diadatkan. Prinsip ini menjadi titik tolak bagi Raja Amai dalam memperkenalkan sekaligus mengembangkan agama Islam di Kerajaan ini. ${ }^{13}$ Untuk melengkapi pemahaman kita tentang pola syariat yang diadatkan, berikut beberapa contoh berdasarkan hasil keputusan seminar adat, antara lain: (a) motolobalango; yang berarti peminangan, adalah pola syariat yang dilaksanakan secara adat dalam sistem perkawinan masyarakat Gorontalo; (b) mengakaji; mengakad, sebagai aspek syariat yang dilaksanakan pula secara adat, berpakaian adat, berbahasa adat, dan gerak-gerik adat.

Dalam rumusan yang kedua oleh Raja Matolodulaakiki (1550-1585) dalam adat bersendi Syara', Syara' bersendi adat. Pola syariat yang dikembangkan dalam paradigma adat dalam masyarakat Gorontalo yang meliputi pola syariat acara pemakaman, mulai dari proses memandikan hingga penguburan, merupakan pola syariat yang dilaksanakan berdasarkan pola adat.

Agama di Gorontalo). Makalah untuk Seminar Adat Daerah Gorontalo, 2007, 2.

13Polontalo, "Sultan..., 8 
Selanjutnya adalah adat dalam komunikasi sosial, yang dalam konteks Gorontalo sangat mengutamakan akhlakul karimah.

Demikian halnya yang berlaku dalam rumusan ketiga, yakni rumusan dikemukakan oleh Raja Eyato (1673-1679), yang secara keseluruhan mendukung prinsip adat bersendi Syara', Syara' bersendi Kitabullah, baik yang berkaitan langsung dengan prinsip keagamaan maupun yang berkaitan dengan prinsipprinsip sosial-kemasyarakatan. Di masa pemerintahan Raja Eyatolah terjadi perubahan sistem pemerintahan, yang mana pemerintahan terdiri dari tiga bagian: (1) Maharaja atau Sultan menjadi Ketua Dewan Tiga Utas Pemerintahan, Buatulo Tolalu, memimpin dua bagian yakni pemerintahan dan adat (Baate sudah di bawah Maharaja); (2) Buatulo Bala; keamanan yang dikepalai Apitalao (kapitan laut); (3) Utas yang baru yakni Buatulo Saraa (Utas Syareat) yang dikepalai oleh seorang Kadhi yang mengurusi masalah agama. Secara rinci tugas Kadhi terdiri dari: (a) mengajarkan agama kepada masyarakat; (b) membangun dan merawat masjid dan wakaf-wakafnya; (c) menyelenggarakan upacara-upacara agama di mesjid maupun di Istana Kerajaan dan ditempat lainnya.

Dalam konteks kekinian, prinsip ataupun falsafah Adat bersendi Syara', Syara' bersendi Kitabullah" yang telah diwarisi oleh masyarakat Gorontalo sejak ratusan tahun yang lalu, dan kini kearifan tersebut menjadi corak bagi keberagamaan mereka. Sebagai masyarakat yang lahir dan dibesarkan di Gorontalo serta memiliki leluhur yang warga Gorontalo, Erwin Y. Thaib ${ }^{14}$ mempersepsikan fenomena keagamaan masyarakat Gorontalo sebagai:

Kenyataan keberagamaan yang sudah demikian dari awalnya, sehingga siapapun orang Gorontalo mau tidak mau harus menerima realitas tersebut. Ciri keberagamaan yang diwarnai oleh corak adat dalam pelaksanaannya, bagi masyarakat Gorontalo merupakan pilihan hidup yang mutlak.

Selanjutnya Thaib mengungkapkan pula bahwa sesungguhnya pelaksanaan ritual keagamaan yang dilaksanakan dengan pola adat di samping merupakan pengejewentahan dari

${ }^{14}$ Hasil Wawancara. 
kearifan Adat bersendi Syara', Syara' bersendi Kitabullah seperti yang diinginkan dan diwariskan oleh leluhur masyarakat Gorontalo, juga merupakan pengejewantahan dari keinginan masyarakat Gorontalo melalui pola adat yang telah terlembagakan. Konteks tersebut tergambar dalam kearifan lokal yang dipahami oleh tokoh-tokoh masyarakat Gorontalo bahwa; adati Madilidiloto Bolomopoaito" (Adat itu telah memiliki pola/berpola-kita tinggal merangkaikannya saja).

Dalam perspektif yang lain Agus Madina ${ }^{15}$ mengungkapkan bahwa:

...yang namanya adat di Gorontalo dengan agama itu dia bagaikan satu koin yang memiliki dua sisi, di sisi satu adalah adat dan di sisi lainnya adalah hal-hal yang meyangkut dengan keagamaan. Hal ini bermakna bahwa kehidupan keagamaan yang disimbolkan melalui prinsip adat bersendikan sara, sara bersendikan kitabullah mengingini suatu kondisi bahwa pelaksanaan adat maupun sebaliknya harus saling mewarnai atau saling memberi corak, dalam artian pelaksanaan adat harus dapat disimbolkan melalui corak agama, demikian halnya agama harus pula dapat disimbolkan melalui adat...

Sementara itu Lukman Katili memberikan apresiasi yang agak berbeda menyangkut fenomena prinsip Adat bersendi Syara', Syara' bersendikan Kitabullah tersebut, yakni falsafah tersebut dalam realisasinya saat ini masih mencari bentuk, apakah prinsip tersebut hanya mencari suasananya atau memang ada aplikasinya, karena kita melihat di Gorontalo adat-adat itu memang memiliki nuansa Islam (agama), tetapi ketika ada pelanggaran-pelanggaran maka secara syariat itu tidak ada sanksi. Namun secara adat orang tersebut akan merasa terkucilkan hidupnya dalam masyarakat. ${ }^{16}$

\section{Corak Mistisisme Islam dalam Tradisi Upacara Keagamaan Masyarakat Gorontalo}

Jika ditelisik lebih dalam pada realitas kehidupan religius masyarakat Gorontalo, maka akan ditemukan suatu fakta bahwa praktek keberagamaan mereka adalah praktek keagamaan yang banyak diwarnai oleh praktek tarekat dalam bentuk ritual

${ }^{15}$ Hasil Wawancara.

${ }^{16}$ Hasil Wawancara. 
peribadatan yang bercorak mistis. Ritual-ritual tersebut terwujud dan termanifestasi dalam berbagai tradisi upacara keagamaan yang dilatari oleh budaya agama dan budaya sosial. Konteks dan konstruk pengamalan upacara keagamaan demikian merupakan implikasi dari warisan Islam masa lalu, yang secara historis geografis, corak keberislaman yang dipraktekkan di bumi Gorontalo adalah cenderung pada Islam yang diamalkan oleh orang-orang dari Ternate dan juga Makassar. ${ }^{17}$ Konteks demikian meniscayakan sebuah pola keberagamaan yang khas dan unik, yang mana penghayatan terhadap wujud Allähu Ahad termanifestasikan dalam teks-teks wirid dan doa selamatan terhadap arwah leluhur dan syukuran terhadap segala rezeki dan karunia yang Ilabi Rabbi persembahkan kepada hambaNya. Kehadiran orang-orang Ternate dan Gowa pada masa lalu yang dilatari oleh konflik, justru memberi warna atau corak tersendiri terhadap khazanah dan model keberislaman masyarakat Gorontalo saat itu, bahkan hingga kini, bahwa kuat dugaan orang-orang tersebut telah mempraktekkan dan menghayati suatu corak khas berdasarkan aliran tarekat tokoh (aliran) tertentu seperti tarekat Qadiriyah, Khalwatiyah, dan Naqsabandiyah, baik yang barasal dari Ternate maupun yang berasal dari Makassar. Untuk konteks Ternate sendiri, sumber tarekatnya adalah berasal dari relasi Islam Ternate-Banten-Makassar, sementara untuk Makassar, ajaran tarekat yang mereka praktekkan diduga bersumber dari ajaran ulama Minangkabau (Dato Ditiro, Dato Rabandang, dan Dato Patimang) yang menjadi motor utama penyebar Islam di Sulawesi Selatan dan ulama kerajaan yang sempat belajar Islam ke Timur Tengah (Mekah) seperti Syekh Yusuf al-Makassari. ${ }^{18}$ Sesuai dengan ijazah yang dimiliki oleh Syekh Yusuf al-Makassari, beliau dapat

${ }^{17}$ Baca misalnya dalam, Hasanuddin \& Sri Suharjo, Gorontalo: Kerajaan Tradisional bingga Kolonial Belanda Suatu Tinjauan Sejarah Sosial Ekonomi (Manado: Balai Kajian Sejarah dan Nilai Tradisional, 2001), 12-7.

${ }^{18}$ Syekh Yusuf adalah orang Makassar, lahir di Kerjaan Gowa pada tahun $1626 \mathrm{M}$, seorang ulama syariat, sufi, dan khalifah tarekat serta seorang musuh besar kompeni Belanda di zamannya. Ia diasingkan ke Ceylon (Sri Lanka), kemudian dipindahkan ke Afrika Selatan dan wafat di Cape Town (Afrika Selatan) pada tahun 1699. Lihat selengkapnya dalam Abu Hamid, Syekh Yusuf Seorang Ulama, Sufi, dan Pejuang (Jakarta: Obor, 2005), xxiii. 
mengajarkan empat macam aliran tarekat yang meliputi; Naqsyabandiyah, Syattariyah, Ba'alawiyah, dan Qadiriyah. Beliau sendiri dikenal sebagai penganjur dan pengajar tarekat Khalwatiyah. ${ }^{19}$

Jika kita menyimak konstruksi historis relasi Islam GowaGorontalo di abad XVII tersebut, maka dapat ditarik benang merah bahwa pengerahan pasukan dimasa lalu juga dibarengi oleh pewarisan ajaran Islam versus laskar Gowa, yang tentunya sedikit banyaknya mereka menjadi penganut dan penganjur Islam tarekat seperti yang diajarkan oleh guru-guru agama mereka termasuk di dalamnya Syekh Yusuf al-Makassari tersebut. Menurut Sofyan Kau, bahwa lafaz-lafaz zikir dan shalawat yang termuat dalam berbagai momen ritual upacara keagamaan, baik yang bersifat tasyakuran (doa syukur) maupun dalam doa arwah (doa mohon keselamatan terhadap roh para leluhur), banyak dipengaruhi oleh berbagai warna aliran tarekat, antara lain Syattariyah, Naqsyabandiyah, Qadiriyah, dan Khalwatiyah. Namun diduga yang lebih dominan adalah ajaran tarekat Naqsyabandiyah dan Qadiriyah. ${ }^{20}$

Sekalipun corak tahlil dan shalawat yang ditemukan dalam teks-teks lafaz dan doa adalah dominan corak dari kedua aliran tarekat tersebut di atas, tidak berarti bahwa kedua aliran tarekat/mistik tasawuf tersebut diterima melalui pengajaran yang resmi atau yang lebih populer dengan istilah metode guru-murid, alasannya adalah tidak ditemukannya satupun pengamal dari kedua tarekat tersebut di wilayah Gorontalo yang memiliki ijazah resmi sebagai pengikut/penganjur (mursyid) yang diterbitkan oleh alira-aliran tarekat tersebut, bahkan sekalipun awwalul Islam terdahulu yang mereka-mereka diduga merupakan generasi pertama dari pengamal dan penganjur Islam di bumi Gorontalo. ${ }^{21}$

Dalam risalah "Sirr al-Asrār wa Muģhir fì mā Yabtaju Ilayh alAbrār"22, karya Syekh Abdul Qadir Jailani, dikemukakan bahwa

${ }^{19}$ Ibid., xxiv

${ }^{20}$ Hasil Wawancara.

${ }^{21}$ Hasil Wawancara.

22Telah diterjemahkan dengan judul "Titian Mahabba: Jalan Spiritual Menuju sang Khaliq", terj. Ahmad Fadhil (Jakarta: Sahara Publishers, 2003). 
zikir-zikir itu bertingkat-tingkat sesuai kedudukan spiritual, baik yang jelas ataupun samar; mulai dari zikir lisan, zikir jiwa, zikir hati, zikir roh, zikir nurani, zikir samar, hingga zikir yang paling samar. Zikir lisan akan mengingatkan hati seseorang kepada mengingat Allah tatkala melupakannya. Zikir jiwa adalah zikir yang tak terdengar dengan huruf dan suara, melainkan terdengar dengan indra dan gerakan batiniah. Zikir hati adalah perhatian hati terhadap Keagungan dan Keindahan Allah di dalam sanubari. Zikir roh adalah penyaksian cahaya-cahaya penyingkapan Sifat-sifat Allah. Zikir nurani adalah pengawasan yang penuh konsentrasi terhadap penyingkapan Rahasia-rahasia Ilahi. Zikir samar adalah beriringannya Cahaya-cahaya Keindahan Eksistensi Keesaan Transendensi di tempat yang disenangi. Sedangkan zikir yang paling samar adalah memandang Hakekat Yang Maha Benar lagi Maha Yakin, yang tidak diketahui oleh selain Allah Ta'ala. Dia berfirman: "Sesunggubnya Dia mengetabui rahasia dan yang lebih tersembunyi" (Q.s. Thaba [20]: 7). Itulah tujuan yang tertinggi dan yang terakhir. ${ }^{23}$

Selanjutnya disampaikan bahwa jalan menuju Allah senantiasanya jasad berada di jalan yang lurus dengan cara melaksanakan syariat siang dan malam, sedangkan kesenantiasaan roh (hati) mengingat Allah hanyalah kewajiban agama bagi orang-orang yang menempuh jalan spiritual. ${ }^{24}$ Konteks tersebut diapresiasi oleh Iwan Ismail (39) 25 seorang pengamal ajaran tarekat dan salah seorang praktisi/pemimpin doa dan zikir dalam upacara keagamaan di kota Gorontalo mengungkapkan bahwa terdapat dua jalan menuju Tuhan yakni jalan terang/jazad dan jalan sir/rahasia (tersembunyi). Jika jalan yang pertama merupakan jalan yang ditempuh oleh golongan awam (umat biasa) dalam berislam, maka jalan kedua merupakan jalan yang dipilih oleh kaum "pilihan", yakni kaum khawās (khusus) bahkan "khawāsul khawāạ", yakni kaum yang memilih jalan sufistik (mistisisme) dalam menuju ma'rifatullah.

Selanjutnya doa zikir dan shalawat yang bercorak tarekat tertentu seperti Naqsyabandiyah dan Qadiriyah (ini yang

${ }^{23}$ Ibid., 79

${ }^{24}$ Ibid., 80

${ }^{25}$ Hasil Wawancara. 
dominan) ditemukan dalam klasifikasi berbagai tata upacara keagamaan yang berbasis adat lokal Gorontalo. Upacara-upacara sosial keagamaan dimaksud meliputi doa untuk keselamatan arwah leluhur ataupun para nenek moyang yang telah meninggal dunia, di samping itu terdapat pula tradisi upacara sosial keagamaan yang digelar dimaksudkan untuk mengungkapkan rasa syukur atas nikmat rezeki dan usia panjang yang diberikan Allah kepada para hamba-Nya. Tradisi upacara yang masuk kategori doa arwah (selamatan) meliputi upacara gunting rambut, doa arwah dalam rangka memasuki bulan suci Ramadhan, Maulid Nabi, memasuki Tahun baru Islam, dan Nuzulul Qur'an. Adapun wirid yang dilafazkan dengan pola tarekat adalah tahlil dengan lafaz là ilāha illā al-Läh. Sementara untuk kategori doa syukuran maka di dalamnya dilakukan shalawat Nabi Muhammad Saw., dan dinisbatkan kepada sang wali suci Abdul Qadir Jailani ataupun tokoh-tarekat/sufi yang lain. Adapun upacara keagamaan dalam kategori ini meliputi; Naik Rumah Baru, Mensyukuri Kendaraan baru, Mandi Lemon, dan Raba Puru.

\section{Catatan Akhir}

Dalam prakteknya, agama hanya melibatkan dogma agama an sich, namun juga mengakomodir kultur nilai lokal setempat. Eksistensi Islam sangat dipengaruhi oleh lingkungan sosial di mana ia tumbuh dan berkembang. Oleh karena itu, dinamika Islam dalam sejarah peradaban umat manusia sangat ditentukan oleh pergumulan sosial yang pada akhirnya akan sangat berpengaruh dalam memberi warna, corak, dan karakter Islam. Reproduksi wajah agama oleh karena persetubuhannya dengan dimensi historisitas (yang khas, unik, dan partikular) menghasilkan sebuah bentukan baru Islam yang akomodatif, kolaboratif, dan sinkretik, yaitu realitas keberagamaan yang mengadopsi unsur lokal yang tidak bertentangan dengan Islam dan menguatkan ajaran Islam melalui proses transformasi secara terus-menerus melalui interaksi Islam dengan tradisi dan budaya masyarakat lokal tanpa kehilangan arah ortodoksi Islam. Mistisisme yang ditampilkan oleh masyarakat Islam Gorontalo merupakan salah satu representasi dari ummat Islam di 
Indonesia yang memiliki kecenderungan untuk senantiasa mensinergikan ajaran agama (Islam) dengan budaya lokal dengan mengusung terma al-muhāfazah 'alà qadìm al-sālị̣ wa al-akbdhu bi al-jadid al-așlah. (menjaga tradisi lama yang baik dan mengambil tradisi baru yang lebih baik). Hubungan antara Islam dengan isuisu lokal adalah kegairahan yang tak pernah usai. Hubungan intim antara keduanya dipicu oleh kegairahan pengikut Islam yang mengimani agamanya: săhịhun li kullì zamān wa makānselalu baik untuk setiap waktu dan tempat. Maka Islam akan senatiasa dihadirkan dan diajak bersentuhan dengan keanekaragaman konteks. Wa al-Lāh a 'lam bi al-șawäb.

\section{Daftar Pustaka}

Arifin, Arifin, dkk., 1996. Spiritualisasi Islam dan Peradaban Masa Depan. Yogyakarta: SIPRESS.

Baal. J. Van. 1987. Sejarah Pertumbuhan Teori Antropologi Budaya. Jakarta: Gramedia.

Depdiknas. tth. Kamus Besar Bahasa Indonesia. Jakarta: Balai Pustaka.

Hamid, Abu. 2005. Syekh Yusuf Seorang Ulama, Sufi, dan Pejuang. Jakarta: Obor.

Moleong, Lexy J. 1991. Metodologi Penelitian Kualitatif. Bandung: Remaja Rosdakarya.

Nur. S.R. 1996. Islam dan Etos Kerja Masyarakat Gorontalo. Jakarta: Yayasan Festival Istiqlal.

Polontalo, Ibrahim. 1991. "Sultan Amai Pencetus Sejarah Islam di Gorontalo". Makalah Seminar.

Polontalo, Ibrahim. 2003. "Masuk dan Berkembangnya Islam di Gorontalo Sejak Awal Abad Ke XVI Sampai Abad Ke XIX”, Makalah. IKIP Negeri Gorontalo. 